\title{
EXPERIMENTAL FIBROSITIS DUE TO A VIRUS, AND SOME OBSERVATIONS ON THE EXPERI- MENTAL PRODUCTION OF ARTHRITIS*
}

\author{
BY MERVYN H. GORDON
}

\section{EXPERIMENTS WITH a VIRUS}

Observations were made in the first place with a pathogenic strain of variola-lapine, the M4 strain of Tulloch originally raised by Sobernheim by inoculating rabbits with smallpox crusts. In order to develop its virulence to the fullest degree, this virus was first passaged through the testis of a series of rabbits. The chief material used consisted of a 1:50 suspension of the passage testis in broth that was centrifuged for thirty minutes at 3,000 r.p.m. to remove the heavier particles. The clear supernatant fluid was sterile on culture and active on the rabbit's skin up to a dilution of over 1:1,000,000. In some experiments a broth suspension of the young papules on the rabbit's skin three days after scarification was employed, and the results were similar.

The inquiry was undertaken expressly in view of the present discussion, and the primary object was to see if by repeated doses venously this M4 virus produced malignant endocarditis in rabbits. It was found, however, that by giving two doses venously separated by an interval of four days the rabbits developed symptoms of arthritis (limp on moving). When the dose was too large or the virus especially virulent a polyarthritis developed, but usually only one hind leg was affected. On palpating the affected joint the lesion was found to be periarticular rather than articular, and the commonest site was in the region of the insertion of the tendo Achillis (see Fig. 1). These periarticular swellings never suppurated, and if left alone gradually cleared up. When the rabbit was killed at an early

* Discussion on the Atiology of Acute Rheumatism and Rheumatoid Arthritis. B.M.A. Annual Meeting, Plymouth, Pathology Section, July 20, 1938. 
stage of the lesion and the skin removed, the subcutaneous tissue was found to be charged with a serofibrinous exudate that was sterile on culture, and contained the virus up to a dilution of over 1:1,000,000 at first, later only to $1: 1,000$, and later still (eleventh day) none at all. Titration of the blood and spleen at the time that the virus was most abundant in the lesion only showed the virus up to $1: 10$ or less. The gland draining the affected area (usually the popliteal) contained the virus in almost as great an amount as the exudate.

These periarticular swellings, therefore, that generally appeared within a day or two of the second venous injection, and sometimes before, were due to the active proliferation of the virus at that site at a time when it was relatively scarce elsewhere in the body. Chief interest, however, attaches to the sections of the affected tissues, for these clearly showed two things: First, that the cells of the exudate mainly consisted of lymphocytes; and, second, that the brunt of the attack was on the fibrous tissue, especially the covering sheaths and aponeuroses of the vessels, nerves, and tendons - in short, a fibrositis. In at least one case the periosteum also was involved. As these changes recalled those described in his book by Ralph Stockman, the pioneer on this subject, I asked him to look at some of the sections, which he very kindly did, and he permits me to say that in his opinion these lesions produced in rabbits by M4 virus are similar to those of rheumatic fibrositis in man. At the same time he is of opinion that similar changes can be produced by other agencies-e.g., trauma, etc. Nevertheless, the experimental production of periarticular fibrositis in rabbits by the local multiplication of a virulent strain of lapine introduced by the venous route is sufficiently interesting in relation to the genesis of rheumatism, since fibrositis is one of its most prominent clinical features and bacteria appear to be absent. When the virulence of the M4 virus became attenuated, periarticular lesions were no longer produced by it, but after repassage this power was regained.

\section{Control Observations}

Control observations were made by injecting rabbits venously in the same way with normal horse serum, and with one-day broth cultures enriched with rabbit serum of a number of bacteria. Two doses of 1 c.c., followed by a third dose of 2 c.c., gave negative 
results in case of the horse serum, B. coli, and Staphylococcus epidermidis respectively. A virulent specimen of Staphylococcus aureus killed the rabbit with septicæmia in twenty-four hours after the intravenous injection of 1 c.c. The culture was diluted $1: 10$ in broth and no arthritis was produced by 1 c.c., followed four days later by 2 c.c., but after a third dose of 4 c.c. severe arthritis occurred in one joint (knee) accompanied by considerable swelling of the whole joint. By far the most active organism, however, up to the present of those tested for producing arthritis in the rabbit by the venous route is Streptococcus hoemolyticus, of which a strain, "David," given to me by Dr. L. P. Garrod,

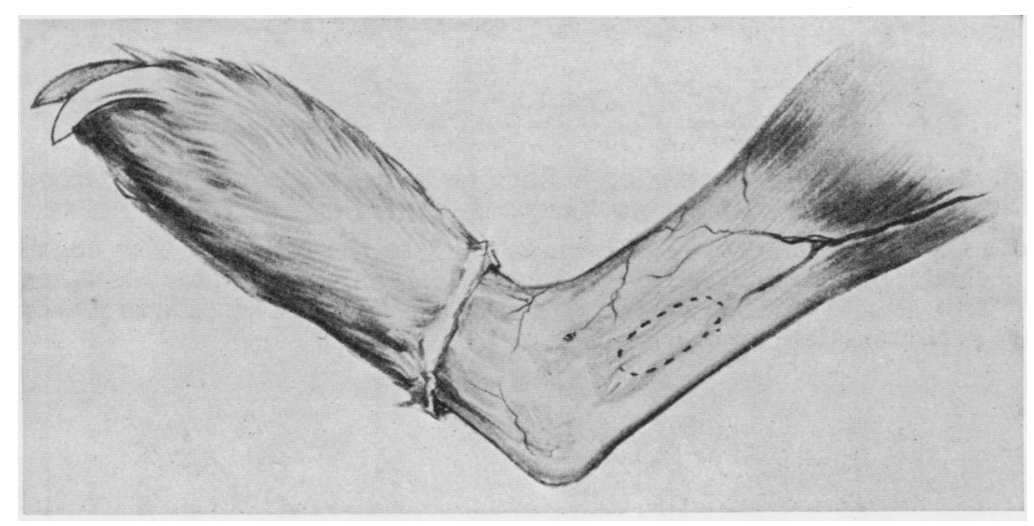

Fig. 1.-Drawing of Hind Leg of Rabbit with Skin Removed to show the Usual Site of the Palpable Swelling between the Tendo AChILlis and Bone produced by the M4 Virus when INJECTED INTRAVENOUSLY.

was chosen. It had been isolated from the tonsil and was selected because it was not sufficiently pathogenic to kill the rabbit by septicæmia. With 1 c.c., or 0.5 c.c. sometimes, of a one-day serum broth culture of this streptococcus arthritis was frequent after the second dose. As a rule the arthritis seemed to be limited to the joint, but in some a periarticular swelling could be felt around the tendo Achillis. Further investigation of this streptococcal arthritis has not yet been made. It may be of interest to state that a rabbit that had received two small doses of the living streptococcus without arthritis developed it later on receiving a large dose venously of hæmolytic streptococcus killed by heating it to $65^{\circ} \mathrm{C}$. 


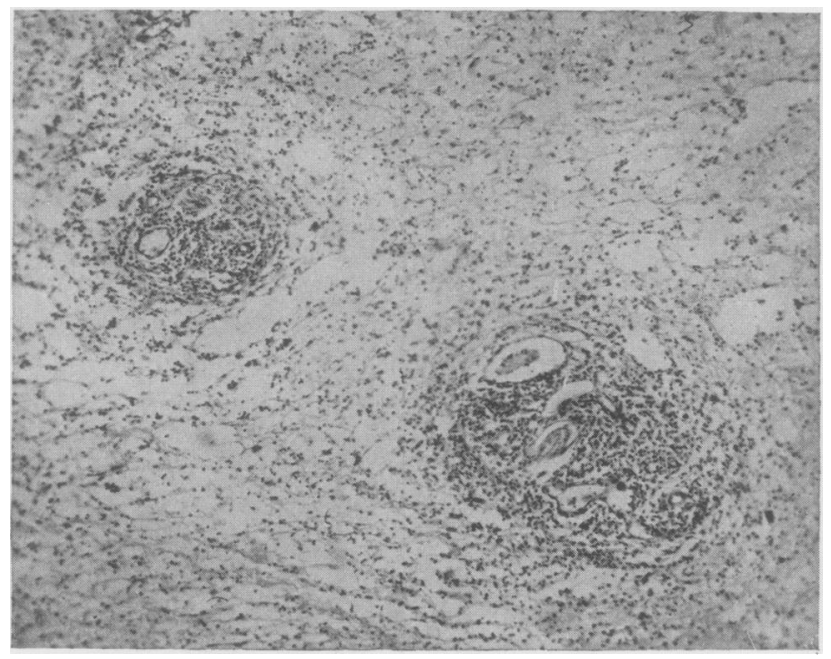

Fig. 2.-Low-Power View of a Section through the Subcutaneous Swelling near the Right Tendo Achillis of R.39, Sixth Day.

Note the background of serofibrinous exudate the cells of which consist chiefly of lymphocytes, and the foci in the connective tissue supporting two groups of bloodvessels and nerves. The M4 virus was present in this exudate up to a dilution of $1: 10,000,000$.

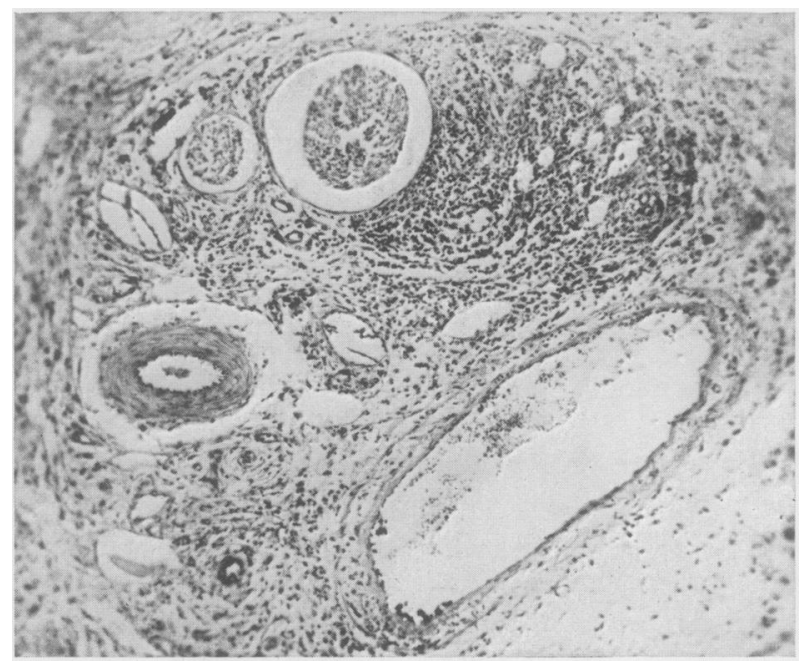

Fig. 3.-One of the Foci as seen in Fig. 2, under a Higher Power.

The connective tissue framework around the vein, artery, and nerves is swollen and inflamed, and a mass of lymphocytes is present in the sheathing of a nerve. 


\section{Mixture of Virus and Streptococcus}

The next step was to see the effect of mixing the M4 virus with the David streptococcus. Preliminary experiments were made to find the minimal dose of each that gave rise to arthritis or periarthritis when given by vein, and then one-half and onequarter respectively of that amount of each was pooled and tested. Evidence was found that arthritis production was increased by mixing the virus and streptococcus in this way, and I was surprised to find that the virus alone could be recovered from the lesions

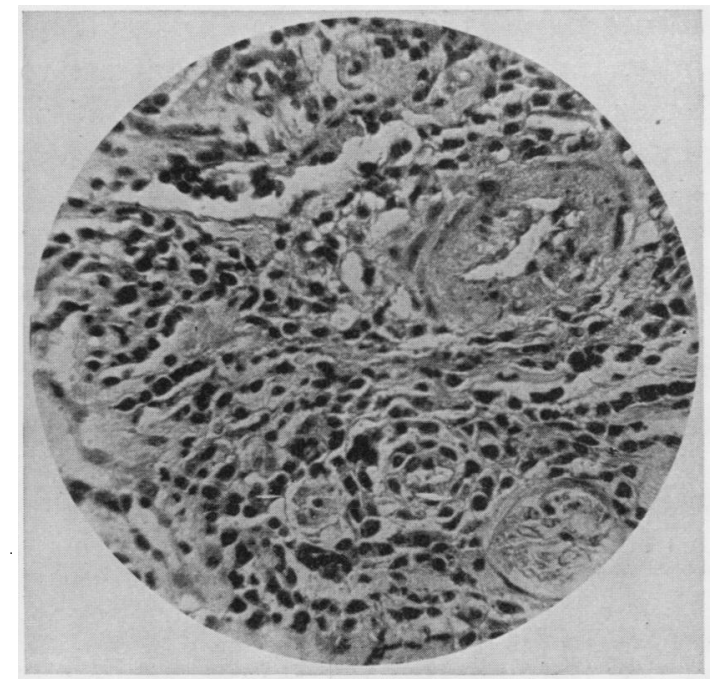

Fig. 4.- Later Stage of the Same Process, R.40, Eleventh Day. Fibrocytes are now in active proliferation and fibrosis is in progress.

and elsewhere in the affected animals. On repeating the experiment by the intracutaneous route the streptococcus again disappeared, the virus surviving. At that point I was reminded of an observation made by Craigie and Tulloch in course of their study of vaccinia and recorded in their report to the M.R.C. in 1931-namely, that rabbit pulp containing vaccinia virus exerts an inhibitory effect in vitro on staphylococcus when mixed with it in an agar plate, a property not manifested by similar pulp prepared from the normal rabbit, and therefore due to the virus itself. I have tried to see whether M4 virus has a similar inhibitory effect on the David streptococcus in vitro, but so far the 
results have not been decisively positive. The whole matter is still sub judice.

In conclusion, I would like to emphasise two points: (1) That the experimental production of arthritis in rabbits is worthy of closer investigation, and (2) that the disappearance of the hæmolytic streptococcus when it was mixed with the M4 virus and injected into the rabbit's tissues seems to suggest a possible explanation of a difficulty many have felt in accepting the hæmolytic streptococcus as a primary factor in the rheumatic process. This difficulty is that, in spite of the presence of acute and intense inflammatory changes in the rheumatic tissues, films and cultures from these lesions have in the hands of most of us remained sterile, thus presenting a great contrast to the result given by similar tissues in an ordinary case of streptococcal septicæmia, in which the films and cultures are swarming with the same organism. Should a virus-like agent be present in the tissues during rheumatism that inhibits the growth of the hæmolytic streptococcus its failure to grow can readily be understood.

In the following tables further details are given of the experiments summarised above: Table I, with the M4 virus alone; Table II, with control materials; and Table III, with the mixture of virus and hæmolytic streptococcus. The illustrations show the periarticular lesions produced by the M4 virus by the venous route when its virulence had been raised by passage in the manner described.

\section{TABLE I.}

M4 VIRUS (VARIola-Lapine), R.39: Fibrositis Experiments (Slann 6×24 Hours)

3.3.38: 0.5 c.c. M4 virus venously.

4.3.38: Nil.

7.3.38: 1.0 c.c. $\mathrm{M} 4$ virus venously.

8.3.38: Swelling round right tendo Achillis.

9.3.38: Swelling increased. Slew rabbit.

P.M.-In subcutaneous tissues round right tendo Achillis is a sero-fibrinous exudate.

Popliteal gland (R.) enlarged.

Cultures.-Heart's blood, spleen, gland, exudate, all sterile.

\begin{tabular}{|c|c|c|c|c|c|c|c|c|}
\hline Vir & us : & $1: 10$ & $1: 100$ & $1: 1,000$ & $1: 10,000 \mid$ & $1: 100,000$ & $1: M$ & $1: 10 M$ \\
\hline Heart's blood & . & + & - & - & - & - & - & - \\
\hline Spleen & $\cdots$ & + & - & - & - & - & - & - \\
\hline Popliteal gland & .. & + & + & + & + & + & - & - \\
\hline Exudate .. & . & + & + & + & + & + & + & + \\
\hline
\end{tabular}

$+=$ Vaccinia lesion developed on rabbit's skin. 


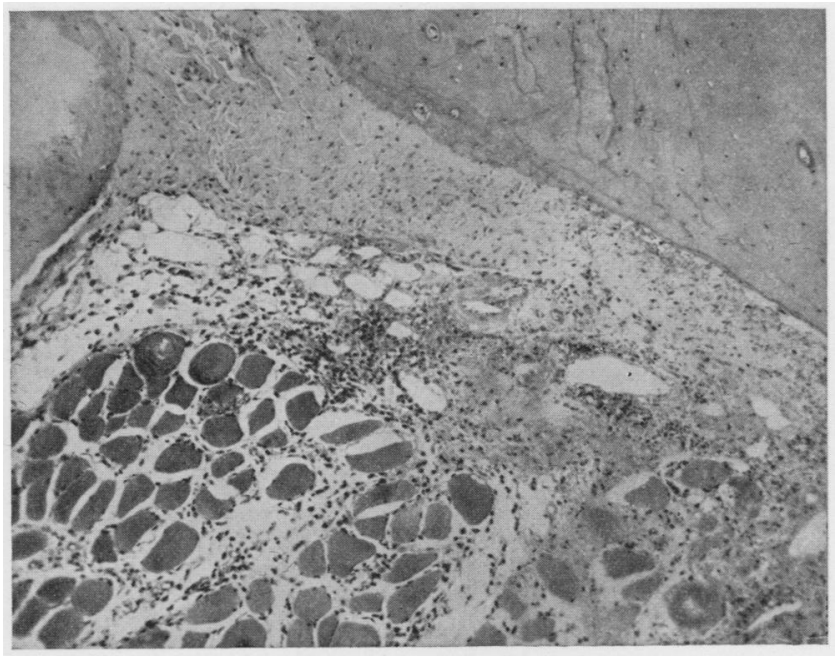

Fig. 5.-Low-Power View of Section throdgh the Bone (Ulna), Periosteum, and Muscle near Affected Joint of the Left Foreleg of R.42, Eighth Day.

Note the periostitis, fibrositis, and interstitial myositis-the inflammation spreading in the connective tissues between the bundles of muscle fibres. The M4 virus was present in this exudate up to a dilution of at least $1: 100,000$.

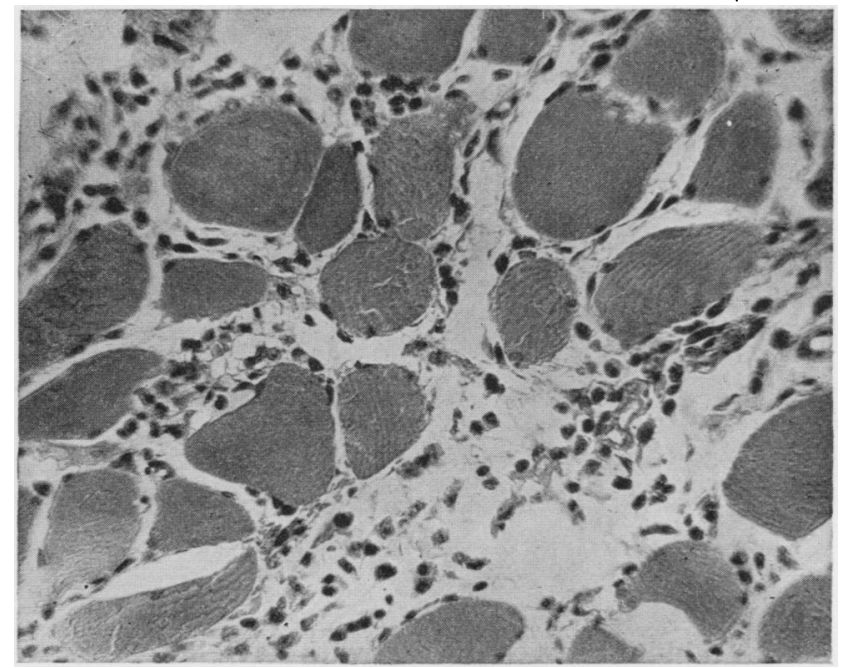

Fig. 6.-Portion of the Same Section under a Higher Power to show the Character of the Cellular Exudate between the MUSCle Bundles. 

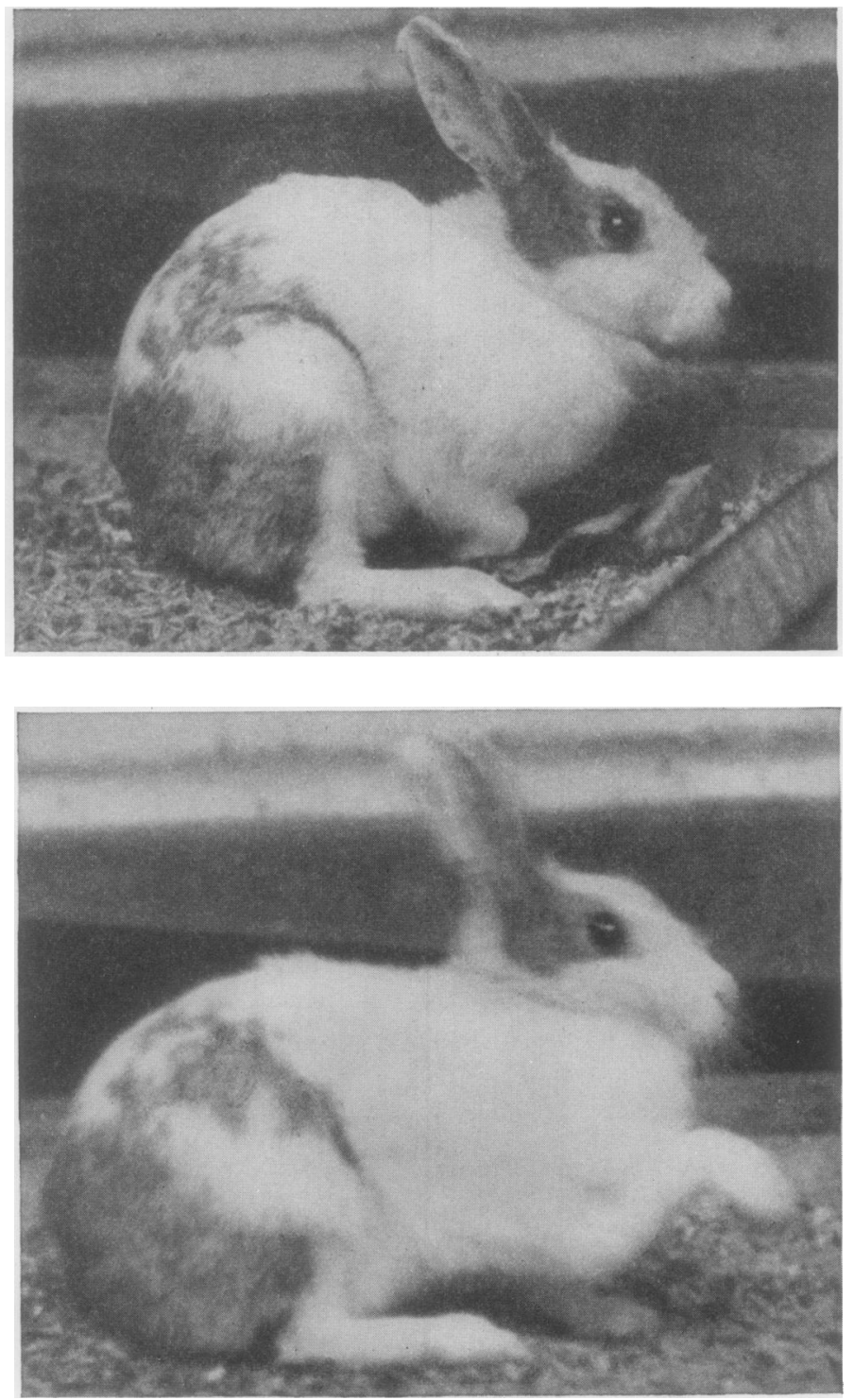

Figs. 7 and 8.-Photograph of R.48 Twelve Days after receiving intravenously a Dose consisting of Equal PartsLof M4 Virus AND Hemolytic StReptococcus.

Fig. 7 shows the rabbit at rest in the cage with its right forepaw retracted. In Fig. 8 the right foreleg is being lifted, but the movement is limited owing to arthritis of the right elbow-joint that on palpation was found to be swollen and rigid. Later on this cleared up and normal movement was regained. 
M4 VIRUS (Variola-Lapine), R.42: Fibrositis Experiments (Slain

28.3.38: 1.0 c.c. virus venously. $7 \times 24$ HoURs)

30.3.38: $2 \cdot 0$ c.c. virus venously.

31.3.38: Nil.

1.4.38: Periarthritis right ankle. This increased and the other ankle affected; also left " wrist."

4.4.38: Slew R.

P.M.-Cultures.-Blood, spleen, popliteal gland (R.), and ankle exudate sterile.

\begin{tabular}{|c|c|c|c|c|c|c|c|c|}
\hline \multicolumn{2}{|r|}{ Virus : } & $1: 10$ & $1: 100$ & $1: 1,000$ & $1: 10,000$ & $1: 100,000$ & \multirow[t]{2}{*}{$1: \mathbf{M}$} & \multirow[t]{2}{*}{$1: 10 M$} \\
\hline Heart's & lood & - & - & & & & & \\
\hline Spleen & .. & $(+)$ & - & & & & & \\
\hline \multicolumn{2}{|c|}{ Popliteal gland (R.) } & + & + & + & - & - & & \\
\hline \multicolumn{2}{|c|}{ Popliteal gland (L.) } & + & + & + & + & - & & \\
\hline \multicolumn{2}{|c|}{ Wrist (L.) exudate } & + & + & + & + & + & & \\
\hline
\end{tabular}

TABLE II.-ARTHRITIS EXPERIMENTS

\begin{tabular}{|c|c|c|}
\hline \multicolumn{2}{|l|}{ Controls. } & \multirow{2}{*}{ Result. } \\
\hline Material. & Dosage. & \\
\hline Normal horse serum & $\begin{array}{l}\text { 27.5: } 1 \text { c.c. } \\
\text { 31.5: } 1 \text { c.c. } \\
\text { 13.6: } 2 \text { c.c. }\end{array}$ & Nil. \\
\hline $\begin{array}{l}\text { Staphylococcus epidermidis } \\
\text { serum broth }\end{array}$ & Ditto & Nil. \\
\hline B. coli serum broth & Ditto & Nil. \\
\hline Staphylococcus aureus .. & Ditto & Dead of septicæmia 24 hours. \\
\hline $\begin{array}{l}\text { Staphylococcus } \\
1: 10 \text { dilution }\end{array}$ & $\begin{array}{l}1 \text { c.c. } \\
2 \text { c.c. } \\
4 \text { c.c. }\end{array}$ & $\begin{array}{l}\text { Nil after first two doses. Arth- } \\
\text { ritis } R . \text { knee after third. }\end{array}$ \\
\hline $\begin{array}{l}\text { Streptococcus hoemolyticus } \\
\text { serum broth }\end{array}$ & $\begin{array}{l}1 \text { c.c. } \\
2 \text { c.c. }\end{array}$ & $\begin{array}{l}\text { Two days after second dose, } \\
\text { swelling round R. tendo } \\
\text { Achillis and arthritis. }\end{array}$ \\
\hline $\begin{array}{l}\text { Streptococcus hoemolyticus } \\
\text { serum broth }\end{array}$ & $\begin{array}{l}1 \text { c.c. } \\
1 \text { c.c. } \\
1 \text { c.c. }\end{array}$ & $\begin{array}{l}\text { Arthritis R. elbow after second } \\
\text { dose. }\end{array}$ \\
\hline $\begin{array}{l}\text { Streptococcus hoemolyticus } \\
\text { serum broth }\end{array}$ & $\begin{array}{l}0.5 \text { c.c. } \\
0.5 \text { c.c. } \\
0.5 \text { c.c. }\end{array}$ & Nil. \\
\hline
\end{tabular}


TABLE III.-ARTHRITIS EXPERIMENTS: ADMIXTURE OF EQUAL PARTS VIRUS M4 AND STREPTOCOCCUS HAMOLYTICUS

Experiment $I$.

\begin{tabular}{|c|c|c|c|c|}
\hline Material. & & & Dose. & Result. \\
\hline Streptococcus only .. & . & . & 1 c.c. & Arthritis. \\
\hline Streptococcus only .. & . & . & 0.5 c.c. & Nil. \\
\hline Virus only $\ldots$ & . & . & 1 c.c. & Nil. \\
\hline Streptococcus and virus & . & . & $\left\{\begin{array}{l}0.25 \text { c.c. } \\
0.25 \text { c.c. }\end{array}\right\}$ & Arthritis. \\
\hline
\end{tabular}

Experiment II. $(3 \times 24$ Hours from Start $)$.

\begin{tabular}{|c|c|c|c|c|}
\hline Material. & & & Dose. & Result. \\
\hline Streptococcus only .. & . & . & 0.5 c.c. & Nil. \\
\hline Streptococcus only . . & . & . & 0.25 c.c. & Nil. \\
\hline Virus only $\ldots$ & . & . & 0.5 c.c. & Nil. \\
\hline Virus only $\ldots \quad \ldots$ & . & . & 0.25 c.c. & Nil. \\
\hline Streptococcus and virus & $\cdots$ & . & $\left\{\begin{array}{l}0.25 \text { c.c. } \\
0.25 \text { c.c. }\end{array}\right\}$ & Arthritis. \\
\hline Streptococcus and virus & $\cdots$ & . & $\left\{\begin{array}{l}0 \cdot 125 \text { c.c. } \\
0 \cdot 125 \text { c.c. }\end{array}\right\}$ & Arthritis. \\
\hline
\end{tabular}

\section{REFERENCES}

Craigie, J., ANd Tulloch, W. J. (1931): Medical Research Counci] Special Report, No. 156.

Stockman, RalPh (1920): "Rheumatism and Arthritis." Edinburgh.

The laboratory expenses of this research were met by a grant from the Medical Research Council, to whom this acknowledgment is due. 